MARIO ĆOSIĆ, Ph.D. ${ }^{1}$

(Corresponding author)

E-mail: mcosic@fpz.hr

LUUPKO ŠIMUNOVIĆ, Ph.D. ${ }^{1}$

E-mail: ljsimunovic@fpz.hr

MARIJAN JAKOVLEVIĆ, Ph.D. Candidate ${ }^{1}$

(Corresponding author)

E-mail: mjakovljevic@fpz.hr

${ }^{1}$ University of Zagreb,

Faculty of Transport and Traffic Sciences

Vukelićeva 4, 10000 Zagreb, Croatia
Traffic in the Cities

Preliminary Communication

Submitted: 16 Nov. 2018

Accepted: 29 May 2019

\title{
RELATIONSHIPS BETWEEN EXTERNAL FACTORS AND PEDESTRIAN ACCIDENT BLACKSPOTS - A CASE STUDY OF THE CITY OF ZAGREB
}

\begin{abstract}
Traffic accidents represent a social, health and political challenge in every country. Urban environments are characterized by intense traffic flows on the network, where different conditions resulting in interactions between motorised and non-motorised transport constantly occur, potentially increasing the risk of accidents. Although road accidents are considered as random events in space and time, a highly detailed analysis may establish correlations between road accidents and external factors (road infrastructure, traffic conditions, weather conditions, land use). This paper considers the impact of external factors on road accidents involving pedestrians in the City of Zagreb, which required an analysis of accident blackspots. The research conducted in this paper puts an emphasis on relations between external factors and accident blackspots involving pedestrians. The results can be used in planning pedestrian infrastructure and improving road safety.
\end{abstract}

\section{KEY WORDS}

pedestrian accident; accident blackspot; external factor; association test; contingency table;

\section{INTRODUCTION}

Several factors contribute to the ever-growing problems related to pedestrian safety - large number of pedestrians in urban traffic, characteristics and dynamics of pedestrian movement, insufficient education of all traffic participants, and inadequate infrastructure. According to statistical indicators, a slight decrease in the number of injured pedestrians was observed over the last few years, but this is still considerably lower compared to the total decrease of all the injured participants in the Republic of Croatia. About $80 \%$ of pedestrian accidents in Croatia occur in urban areas. Pedestrians participate in $5-6 \%$ of accidents, with the number of pedestrian fatalities representing 15-20\% of the total fatalities. These data indicate a significant vulnerability of pedestrians in urban areas.

The lack of attention to influential factors and their impact on pedestrian safety in urban areas is the essential reason for conducting systematic research. A high number of traffic accidents alerts on the general state of pedestrian safety on the road network in urban areas. This is caused by incomplete and unsystematic data collection and only partial analysis, which is an additional reason to research this segment of traffic safety and the level of service in urban road traffic networks.

The main purpose of this research is to determine the influence of external factors on the formation of accident blackspots, i.e. to establish connections between causes and consequences in pedestrian traffic accidents. In a broader sense, external factors are considered to be road and environmental factors, while in the narrow sense road infrastructure, traffic conditions, weather conditions and land use are being considered. By a detailed analysis of traffic accidents, it is possible to establish a correlation between the influence of external factors (demographic factors, land use, traffic flow parameters, elements and road equipment) on traffic accidents involving pedestrians.

The research was conducted for the City of Zagreb. The data were collected from several sources, while the fundamental information on traffic accidents was obtained from the central information system of the Ministry of the Interior of the Republic of Croatia (MUP). Other data were obtained from the city authority (City of Zagreb), relating to the data on land use and road infrastructure with associated traffic volumes.

The purpose of this paper is to establish the criteria for determining accident blackspots considering pedestrian safety based on the contextual information 
linking in non-unified databases. The main contribution of the paper is to gain a new insight into the influence of external factors on traffic accidents involving pedestrians in urban areas.

\section{PREVIOUS RESEARCH}

Pedestrians are the most vulnerable group of participants in the traffic system regarding traffic safety. They are more vulnerable than other traffic participants and have a higher risk of having a collision with a larger vehicle with a greater mass and movement speed. Traffic accidents involving pedestrians and motor vehicles are often used for the analyses in many scientific disciplines such as medicine, sociology, traffic planning and spatial planning. Each of these disciplines analyses and explains traffic accidents from their perspective. Medicine analyses the severity of physical injuries and the frequency of accidents. Sociologists and psychologists strive to identify people's behaviour that leads to traffic accidents. Behaviours such as driver tiredness, speeding, intoxication and cell phone usage (distraction), are recognizable social factors that contribute to traffic accidents.

A review of past research has revealed that the definition of TA (i.e. traffic accidents) blackspots is not universally accepted, which forces researchers to rank them on the basis of their severity or frequency [1]. The choice of a blackspot identification method depends on the availability of data and the criteria [2]. The concentration of TA (indicated by blackspots) in the same location may indicate a spatial relationship between TA and the environment and / or road conditions [3]. Accident blackspots reveal the concentration of similar accidents and point to spatial dependence between individual cases that may have common causes [4]. The identification of focal points with identical TA indicates the need for an analysis of causative factors, which is an important step for a proper implementation of countermeasures or safety improvements [5]. Furthermore, the identification of blackspots with identical traffic accidents offers better understanding of spatial patterns and TA clustering, encouraging the development of effective strategies to improve traffic safety [6].

The impact of traffic infrastructure and demographic characteristics of spatial units regarding traffic accidents in England was analysed by Noland and Quddus [7]. The results suggest that urban areas are associated with fewer casualties (especially fatalities) while areas of higher employment density are associated with more casualties. LaScala et al., [8] conducted research in the area of San Francisco regarding the emergence of a TA with pedestrian participation. The research results have shown that pedestrian injuries correlate with the population density, gender and age structure of the local population, employment and ed- ucation. Blasquez and Celies [9] have determined a positive spatial correlation between traffic accidents and the period of the day when they occurred on straight road sections, intersections, and roads without traffic sign regulation. Wedagama et al., [10] developed generalized linear models to determine the impact of land use, population density and number of intersections on the frequency of traffic accidents involving pedestrians.

An overview of available literature shows that the methodological approach to the examination of traffic accidents is different, and it can be said that they are based on the availability and relevance of the data on which the research is being conducted. Therefore, the methods of exploring blackspots in urban areas can be divided into two groups - the simple ones based on the number of traffic accidents over a given period of time, and those more complex ones representing the overall blackspot identification systems, for which all available data are taken into account.

The research that systematically leads to the relations between external factors in urban areas and traffic accidents involving pedestrians is scarce. Accident data are often heterogeneous and the relationships between the data often remain hidden because of incomplete information. The advantage of research today is the development of the advanced computer systems such as GIS (i.e. Geographic Information System) that can show the accident density in different contexts of a wider geo-spatial environment and identify areas with increased risk, all to better understand the causes of TA generation. In spite of the data that were unavailable or difficult to gather, these were used to create new insights to improve road safety in urban areas.

\section{RESEARCH METHODOLOGY}

The research methodology is multidisciplinary and consists of: data collection, identification of blackspots and statistical data processing with detailed analysis of influential external factors significantly contributing to pedestrian traffic accidents.

Data collection. To create a relevant local database, the data on traffic accidents were collected during the years 2012, 2013 and 2014 in Zagreb by the Ministry of the Interior of the Republic of Croatia. For the purposes of research, different pedestrian-vehicle accidents were processed. The data collected from the City of Zagreb are related to land use, road infrastructure and traffic volume. Additional on-field research included data regarding traffic flow structure, and traffic volume for specific locations on the network. Based on the experience and collected data, a unique local database was integrated into the GIS environment. The obtained database served as the basis for conducting further research. 
Blackspot identification for pedestrian accidents. Identification of blackspots, i.e. focal points, implies the procedure for determining locations on the road transport network where an above-average number of traffic accidents occurs, compared to the other similar locations. There is currently no universal definition of a blackspot in road traffic nor is it defined by the law. In [11], the authors mention "blackspot on the road network", a term used for location on the road where there is high risk of traffic accidents. Under the term "high risk", high probability of traffic accident in some areas compared to other areas on the road network is considered, such that traffic accidents occurring in certain locations have severe consequences.

In this paper, the data were obtained from Hrvatske ceste d.o.o. (Croatian road network operator) to identify pedestrian blackspots on the urban road network of the City of Zagreb [12], where the criterion of three or more similar traffic accidents with injuries occurring in a period of three (3) years (same participant groups, same movement directions, same conflict points, etc.) was used.

The QGIS software tool was used for the process of identifying and grouping TAs on the urban road network in the geographic environment. In order to estimate the density of traffic accidents, the Kernel Density Estimation (KDE) method was applied [4]. Using the KDE method, the density of traffic accidents was obtained for each pixel on the output raster, and the result is a map showing the surface in various colours, revealing accident blackspots [13]. Although KDE uses the interpolation technique instead of revealing blackspots directly, the analysts often use it to identify blackspots [14]. In [15], the authors suggested to use the KDE method to determine the areas of high accident density and recommended continuing the research at the micro level.

The process of identifying pedestrian blackspots on the urban road network by grouping three or more of the same traffic accidents consisted of three steps. The first step was to create a heat map of traffic accidents in the QGIS program with a predefined appendix for estimating the core density. In this procedure a raster map was created, i.e. a heat map showing the area with the highest frequency of traffic accidents that share the same characteristics. In the second step, the transformation of the raster form into vector form was made by using the QGIS program. The newly-defined vector form represents polygons in which there are at least three or more grouped locations of traffic accidents. In the third step, the procedure of associating information or encoding was carried out to conduct a statistical analysis. In the coding procedure, every road accident located in the defined polygon (accident focal point) was assigned attribute one (1), and every other traffic accident outside the polygon was assigned attribute zero (0). The process of joining new attributes was performed for each individual traffic accident with the QGIS and MS Excel programs, to prepare a new database for further statistical analysis in the SPSS 20 program.

By using the input data more related to the underlying traffic risk factors such as road and traffic environment, the following independent factors were assumed to be significantly more affected by blackspots: road category, road direction, number of traffic lanes, type of intersection, road characteristics, traffic regulations, speed limit, land use, traffic volume period in a year, visibility conditions and atmospheric conditions.

The analysis was conducted on a sample of 1,333 traffic accidents involving pedestrians. The sample contains a large number of traffic accidents, which were specifically selected for the analysis. As for categorical data, Hi-square test (non-parametric statistics) was used to determine the relations between the observed and expected frequencies, i.e. the influence of certain factors resulting in blackspots. The level of importance 0.05 was used. For easier data exploration, there is also a mosaic plot and a datasheet (contingency table) of the analysed data.

The codes within the contingency table represent: Count - number of pedestrian traffic accidents, Total\% - percentage of the total pedestrian traffic accidents, Col\% - percentage of the count for the column, Row $\%$ - the cell's percentage of the count for the row. The variables in the columns represent pedestrian blackspots: no (0), yes (1). The variables specified in rows represent their type (e.g. primary road - 1, secondary road - 2 , tertiary road -3 , as shown in Table 3 ). The borders of the contingency table display the columns totals (across the bottom), row totals (on the right), and the grand total (lower right corner).

A mosaic plot is a graphical display of cell frequencies regarding the contingency table in which the area marked in the boxes is proportional to the cell frequencies of the contingency table.

\section{CASE STUDY: CITY OF ZAGREB}

For the analysis, the City of Zagreb, which is also the business, commercial, administrative, tourist and university centre of the Republic of Croatia, was selected. The City of Zagreb has a surface area of $641 \mathrm{~km}^{2}$, representing about $1.1 \%$ of the Republic of Croatia. In the city, there are approximately 6,300 streets and city squares, located in 70 settlements. The total length of the road network is about $2,400 \mathrm{~km}$. The City of Zagreb is a self-governing unit divided into 17 urban districts. According to the 2011 census, the City of Zagreb had 790,017 inhabitants, representing approximately $18 \%$ of the total population of the Republic of Croatia. The average population density is 1,232 inhabitants per $\mathrm{km}^{2}$. There are 339,749 motor vehicles registered in the City $(285,279$ private cars) [16]. 
Table 1 - Total number of traffic accidents involving pedestrians in the City of Zagreb

\begin{tabular}{||c|c|c|c||}
\hline Year & Total number of traffic accidents & $\begin{array}{c}\text { Total number of pedestrian-vehicle } \\
\text { accidents }\end{array}$ & $\begin{array}{c}\text { Percentage of the total number } \\
\text { of traffic accidents [\%] }\end{array}$ \\
\hline \hline 2012 & 9,255 & 437 & 4.7 \\
\hline 2013 & 7,644 & 439 & 5.7 \\
\hline 2014 & 6,808 & 457 & 6.7 \\
\hline Total & 23,707 & 1,333 & 5.6 \\
\hline
\end{tabular}

The analysis of pedestrian traffic accidents for the City of Zagreb included 1,333 cases ( $N=1,333)$, which were documented in the MUP database for the years 2012, 2013 and 2014 (Table 1). In these three years, there was a total of 23,707 traffic accidents in the City area, where pedestrian-vehicle accidents had a share of $5.6 \%$.

If shown in absolute figures, the number of pedestrians-vehicle accidents in the observed period has no tendency for growth or decline. However, if we observe the number of traffic accidents in the relative amount (as a percentage of the total number of traffic accidents), there is a noticeable growth tendency - the share of pedestrians-vehicle accidents increased from $4.7 \%$ to $6.7 \%$. By analysing the three-year period, nine pedestrian fatalities occurred per year in the City of Zagreb. There were 400 more or less seriously injured pedestrians per year, accounting for about $90 \%$ of all traffic accidents. It can be concluded that every day in the City of Zagreb there is 1.1 injured pedestrian in traffic (Table 2).

A map of traffic accidents was generated based on the local database using the QGIS program shows a thermal map with locations of increased density of accidents involving pedestrians. The map shows significant differences in locations where traffic accidents occur, by different levels of accidents in different colours. Bright shades of yellow indicate lower accident
Table 2 - Number of pedestrian-vehicle accidents in the City of Zagreb for the period 2012 - 2014, divided by their consequences

\begin{tabular}{||l|c|c|c|c||}
\hline \multirow{2}{*}{$\begin{array}{c}\text { Traffic accident } \\
\text { consequence }\end{array}$} & \multicolumn{4}{|c||}{ Year } \\
\cline { 2 - 5 } & 2012 & 2013 & 2014 & Total \\
\hline \hline With a fatality & 12 & 6 & 9 & 27 \\
\hline $\begin{array}{l}\text { With an injured } \\
\text { person }\end{array}$ & 389 & 392 & 420 & 1,201 \\
\hline $\begin{array}{l}\text { With material } \\
\text { damage }\end{array}$ & 36 & 41 & 28 & 105 \\
\hline Total & 437 & 439 & 457 & 1,333 \\
\hline
\end{tabular}

density, with dark and red shades indicating greater accident density. Dark red tones represent the centres of the focal point, which is the area with six or more traffic accidents. In the case of traffic accidents involving pedestrians, it is noticeable that the greatest accident density is in the city centre and on the main roads.

Figure 1 shows the focal points of traffic accidents involving pedestrians, which share the same characteristics (where the criterion of three or more similar traffic accidents with injuries occurred in a period of three (3) years (same participant groups, same movement directions, same conflict points, etc.). The analysis found that approximately $18 \%$ (240) of all traffic accidents involving pedestrians $(1,333)$ occurred at

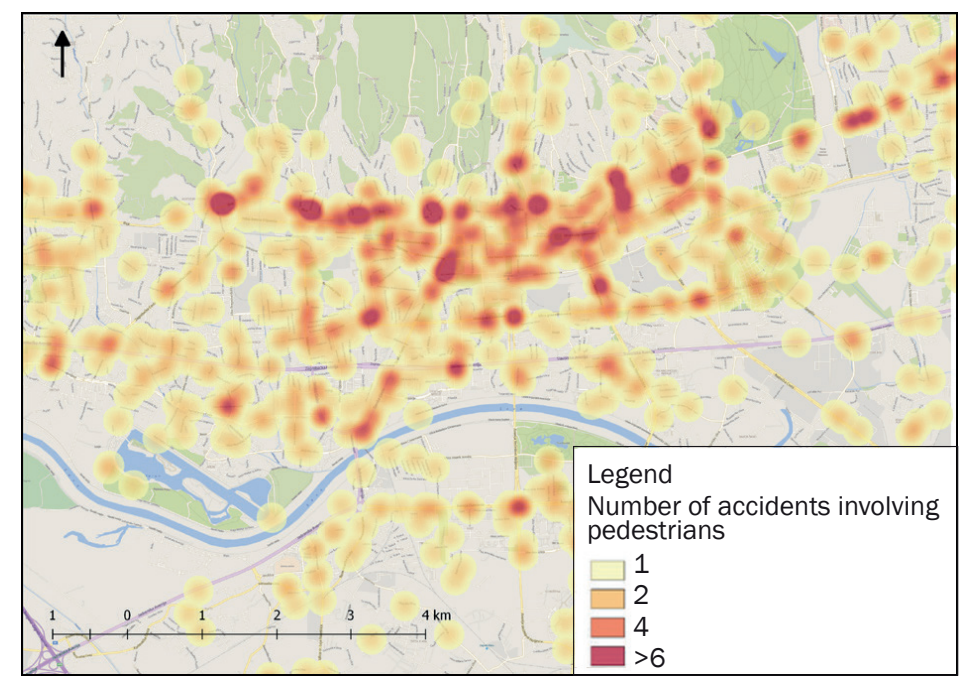

Figure 1 - Heat map of pedestrian traffic accidents in the City of Zagreb, 2012-2014 


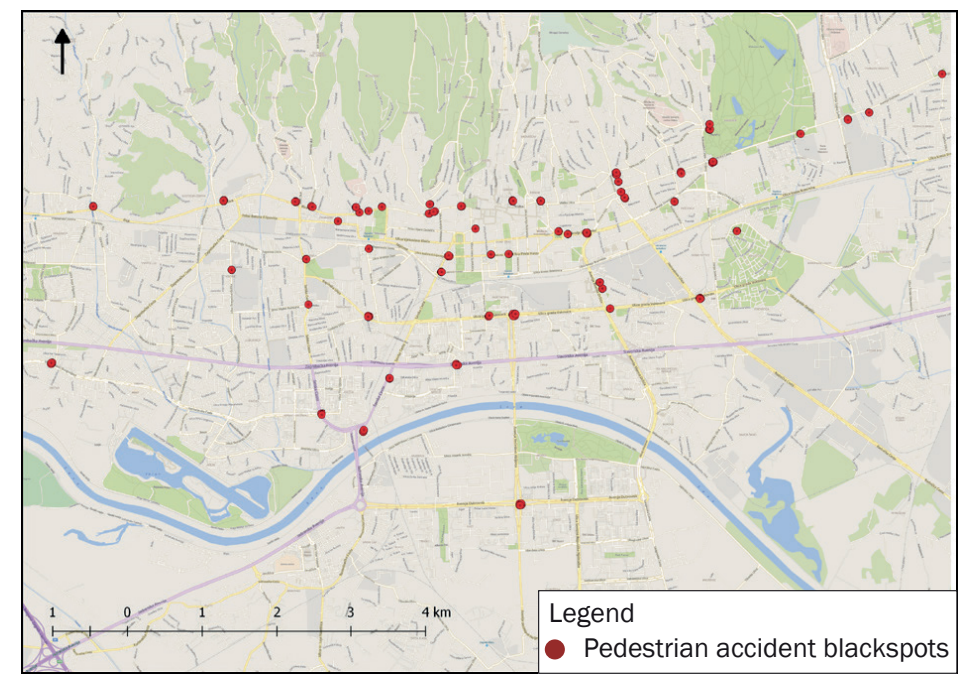

Figure 2 - Pedestrian accident blackspots in the City of Zagreb, 2012-2014

focal points. By analysing the accident density by location, it is concluded that, on average, 4 to 5 traffic accidents occur on blackspots, while approximately 12 accidents occur at all other locations. The conclusion also indicates the existence of certain relationships for accidents at focal points, contrary to accidents at other locations.

\section{RESULTS AND DISCUSSION}

After the collection of relevant data and identification of blackspots, an analysis of the relevant external factors was considered in this paper, having a potential impact on pedestrian blackspots in the City of Zagreb. The identification process determined which traffic accidents fall into the category of blackspots. Also, through the identification process, the statistical significance of certain influential factors was tested. The results of the association test between individual influence factors and the blackspots are demonstrated in this section.

\section{Road category}

For the purpose of establishing an association between the road category and blackspots, the road network of the City of Zagreb, according to the functional classification, is divided into the following three categories: primary (1), secondary (2) and tertiary (3). The network of primary city roads includes: city highways, city avenues and main city streets. The secondary road network consists of city streets and connecting roads, while the network of tertiary roads includes access roads in residential districts, other roads and car parks.

The association test between the emergence of pedestrian blackspots and the road category has determined that their association does exist $\left(\chi^{2}=137.447\right.$ ) $p=<0.0001)$. The analysis of the contingencies in table results (Table 3 ) and Figure 3 show that there is a high
Table 3 - Road category and pedestrian blackspots - contingency table

\begin{tabular}{|c|c|c|c|c|}
\hline \multirow{6}{*}{ 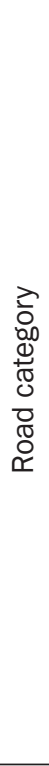 } & \multicolumn{4}{|c|}{ Accident blackspots } \\
\hline & $\begin{array}{l}\text { Count } \\
\text { Total [\%] } \\
\text { Col [\%] } \\
\text { Row [\%] }\end{array}$ & 0 & 1 & \\
\hline & (1) & $\begin{array}{r}464 \\
34.81 \\
42.45 \\
69.77\end{array}$ & $\begin{array}{r}201 \\
15.08 \\
83.75 \\
30.23\end{array}$ & $\begin{array}{r}665 \\
49.89\end{array}$ \\
\hline & (2) & $\begin{array}{r}367 \\
27.53 \\
33.58 \\
91.98\end{array}$ & $\begin{array}{r}32 \\
2.40 \\
13.33 \\
8.02\end{array}$ & $\begin{array}{r}399 \\
29.93\end{array}$ \\
\hline & (3) & $\begin{array}{r}262 \\
19.65 \\
23.97 \\
97.40\end{array}$ & $\begin{array}{r}7 \\
0.53 \\
2.92 \\
2.60\end{array}$ & $\begin{array}{r}269 \\
20.18\end{array}$ \\
\hline & & $\begin{array}{l}1,093 \\
82.00\end{array}$ & $\begin{array}{r}240 \\
18.00\end{array}$ & 1,333 \\
\hline
\end{tabular}

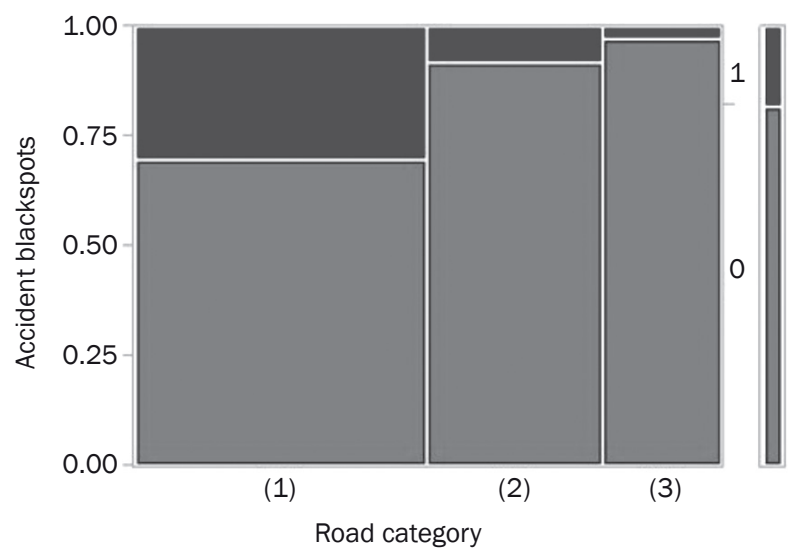

Figure 3 - Correlation of road category and pedestrian blackspots 
probability of pedestrian blackspots on the primary road network, while the lowest probability is on the tertiary road network. The share of traffic accidents on the primary road network covered by the focal points is $30.23 \%$, with $69.77 \%$ of the accident being outside the blackspots. Every other traffic accident occurred on the primary road network (49.89\%). However, the share of traffic accidents on the primary road network that occurred within the focal points represents $83.75 \%$ of TA in relation to the total number of traffic accidents that occurred within the focal points.

\section{Direction and number of lanes}

Considering road direction and the number of traffic lanes, the data on traffic accidents for one-way roads with two or more traffic lanes were analysed. The analysis of the spatial database for the road transport network of the City of Zagreb and the identified blackspots show higher blackspot density on one-way roads with two or more traffic lanes.

For the purposes of establishing relationships between pedestrian blackspots and the number of lanes, each accident has been assigned a new variable

Table 4 - Road direction and pedestrian blackspots - contingency table

\begin{tabular}{|c|c|c|c|c|}
\hline \multirow{5}{*}{ 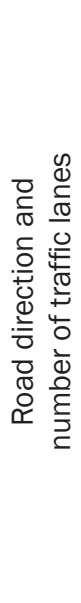 } & \multicolumn{4}{|c|}{ Accident blackspots } \\
\hline & $\begin{array}{l}\text { Count } \\
\text { Total [\%] } \\
\text { Col [\%] } \\
\text { Row [\%] }\end{array}$ & 0 & 1 & \\
\hline & (1) & $\begin{array}{r}775 \\
58.14 \\
70.91 \\
90.01\end{array}$ & $\begin{array}{r}86 \\
6.45 \\
35.83 \\
9.99\end{array}$ & $\begin{array}{r}861 \\
64.59\end{array}$ \\
\hline & (2) & $\begin{array}{r}318 \\
23.86 \\
29.09 \\
67.37\end{array}$ & $\begin{array}{r}154 \\
11.55 \\
64.17 \\
32.63\end{array}$ & $\begin{array}{r}472 \\
35.41\end{array}$ \\
\hline & & $\begin{array}{l}1,093 \\
82.00\end{array}$ & $\begin{array}{r}240 \\
18.00\end{array}$ & 1,333 \\
\hline
\end{tabular}

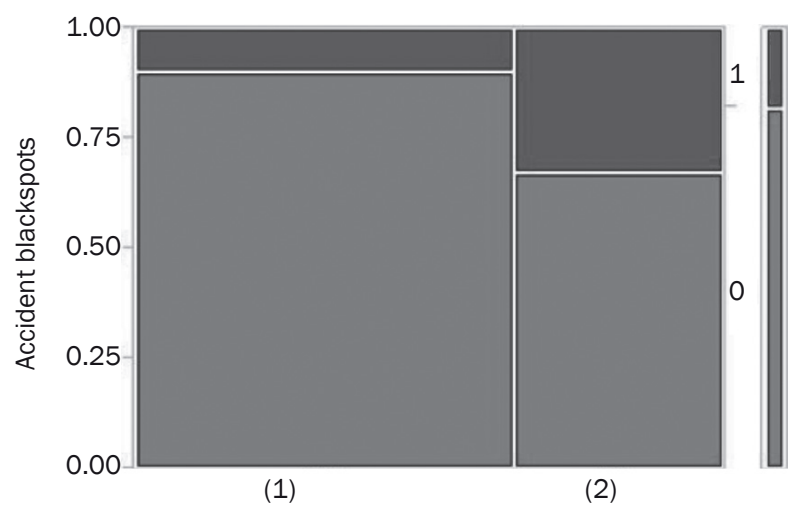

Road direction and number of traffic lanes

Figure 4 - Correlation of road direction and pedestrian blackspots based on its location. Variable 2 indicates that a traffic accident occurred on pedestrian crossings with two or more lanes, on a one-way road. Variable 1 represents all other roads on the network.

The association test between pedestrian blackspots and the road direction combined with the number of lanes determined that their association exists $\left(\chi^{2}=105.840 / p=<0.0001\right)$. The analysis of contingency table results (Table 4 ) and Figure 4 shows a high probability of pedestrian blackspots on one-way traffic roads with two or more traffic lanes. For the purpose of determining the association strength, a risk ratio of 4.364 was used, indicating that the chance of a pedestrian blackspot is four times higher on one-way roads with multiple traffic compared with the rest of the traffic road network (confidence intervals are 3.251 and 5.858). Approximately one third of traffic accidents occur on one-way traffic roads with two or more lanes (35.41\%). The proportion of traffic accidents on oneway roads with two or more traffic lanes is $64.17 \%$ at focal points compared to the total number of traffic accidents at focal points.

\section{Type of intersection - road characteristics}

For the purpose of determining the relationships between the type of intersection and pedestrian blackspots, and based on the analysis of the traffic accident data questionnaire, the intersections were divided into the following categories: three-leg intersection (1), four-leg intersection (2), roundabouts (3) and other road characteristics (straight road section, curve, parking lot, sidewalk, bridge, etc.) indicated by (4).

The association test between the emergence of pedestrian blackspots and the intersection type determined that their association does exist $\left(\chi^{2}=86.448\right.$ / $p=<0.0001$ ). The analysis of the contingency table results (Table 5) and Figure 5 shows that there is a high probability of pedestrian blackspots at roundabouts (50\%), at four-leg intersections (30.68\%) and threeleg intersections (20.30\%). At locations with four-leg and three-leg intersections, $25 \%$ of traffic accidents occurred, and only $1.5 \%$ at roundabouts. However, the share of traffic accidents at three-leg intersections that occur at focal points is $43.33 \%, 28.33 \%$ at fourleg intersections, and $4 \%$ at roundabouts, all in relation to the total number of traffic accidents occurring at focal points.

\section{Traffic regulations}

For the purpose of establishing relationships between traffic regulation type and blackspots, based on traffic accident analysis and the network spatial database of the City of Zagreb, there were two basic categories: without traffic lights (1) and with traffic 
Table 5 - Intersection type and pedestrian blackspots - contingency table

\begin{tabular}{|c|c|c|c|c|}
\hline \multirow{7}{*}{ 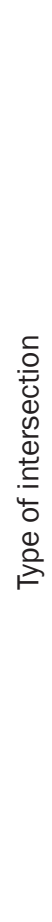 } & \multicolumn{4}{|c|}{ Accident blackspots } \\
\hline & $\begin{array}{l}\text { Count } \\
\text { Total [\%] } \\
\text { Col [\%] } \\
\text { Row [\%] }\end{array}$ & 0 & 1 & \\
\hline & (1) & $\begin{array}{r}267 \\
20.03 \\
24.43 \\
79.70\end{array}$ & $\begin{array}{r}68 \\
5.10 \\
28.33 \\
20.30\end{array}$ & $\begin{array}{r}335 \\
25.13\end{array}$ \\
\hline & (2) & $\begin{array}{r}235 \\
17.63 \\
21.50 \\
69.32\end{array}$ & $\begin{array}{r}104 \\
7.80 \\
43.33 \\
30.68\end{array}$ & $\begin{array}{r}339 \\
25.43\end{array}$ \\
\hline & (3) & $\begin{array}{r}10 \\
0.75 \\
0.91 \\
50.00\end{array}$ & $\begin{array}{r}10 \\
0.75 \\
4.17 \\
50.00\end{array}$ & $\begin{array}{r}20 \\
1.50\end{array}$ \\
\hline & (4) & $\begin{array}{r}581 \\
43.59 \\
53.16 \\
90.92\end{array}$ & $\begin{array}{r}58 \\
4.35 \\
24.17 \\
9.08\end{array}$ & $\begin{array}{r}639 \\
47.94\end{array}$ \\
\hline & & $\begin{array}{l}1,093 \\
82.00\end{array}$ & $\begin{array}{r}240 \\
18.00\end{array}$ & 1,333 \\
\hline
\end{tabular}

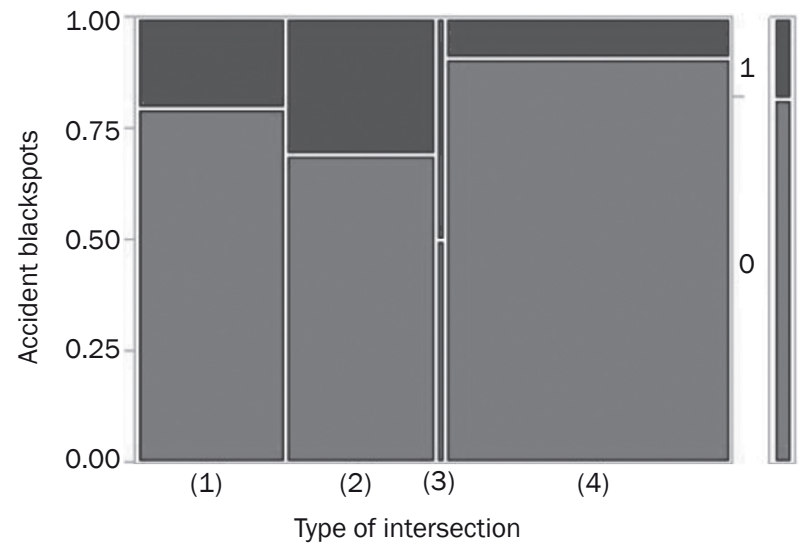

Figure 5 - Correlation between the type of intersection and blackspots

lights (2), such that the former category includes traffic signs, basic regulations and regulation by the traffic police.

The association test between the emergence of pedestrian blackspots and the traffic regulation has determined that their association does exist $\left(\chi^{2}=63.763\right.$ $/ p=<0.0001)$. The analysis of the contingencies table results (Table 6) and Figure 6 shows a higher probability of pedestrian blackspots where there are traffic lights involved. To determine the association strength, a risk ratio of 3.286 was used, indicating that the probability of pedestrian blackspots are three times higher with traffic lights compared to those without traffic lights (confidence intervals are 2.430 and 4.445). On average, every $5^{\text {th }}$ traffic accident $(21.31 \%)$ occurred
Table 6 - Traffic regulations and pedestrian

blackspots - contingency table

\begin{tabular}{|c|c|c|c|c|}
\hline \multirow{5}{*}{ 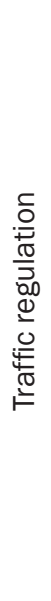 } & \multicolumn{4}{|c|}{ Accident blackspots } \\
\hline & $\begin{array}{l}\text { Count } \\
\text { Total [\%] } \\
\text { Col [\%] } \\
\text { Row [\%] }\end{array}$ & 0 & 1 & \\
\hline & (1) & $\begin{array}{r}906 \\
67.97 \\
82.89 \\
86.37\end{array}$ & $\begin{array}{r}143 \\
10.73 \\
59.58 \\
13.63\end{array}$ & $\begin{array}{l}1,049 \\
78.69\end{array}$ \\
\hline & (2) & $\begin{array}{r}187 \\
14.03 \\
17.11 \\
65.85\end{array}$ & $\begin{array}{r}97 \\
7.28 \\
40.42 \\
34.15\end{array}$ & $\begin{array}{r}284 \\
21.31\end{array}$ \\
\hline & & $\begin{array}{l}1,093 \\
82.00\end{array}$ & $\begin{array}{r}240 \\
18.00\end{array}$ & 1,333 \\
\hline
\end{tabular}

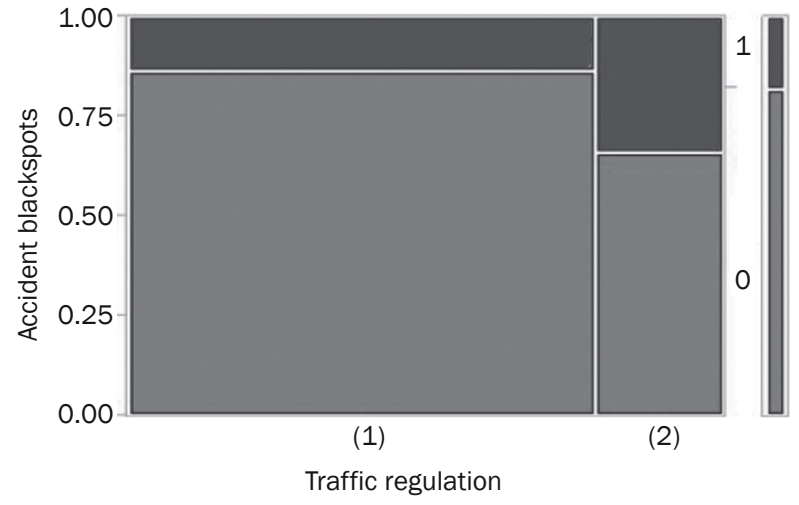

Figure 6 - Correlation between traffic regulation and pedestrian blackspots

under the traffic lights. However, the share of traffic accidents occurring with traffic lights represents $40.42 \%$ of the total number of traffic accidents occurring at blackspots.

\section{Speed limit}

For the purposes of establishing the relationships between the legal speed limit and the blackspots, based on an analysis of traffic accident data and spatial road traffic network database in Zagreb, the traffic accidents were divided into two main categories: accidents on roads with legal speed limit under $50 \mathrm{~km} / \mathrm{h}$ (1) and accidents on roads with legal speed limit equal to or greater than $50 \mathrm{~km} / \mathrm{h}$ (2). Given the fact that on most urban area roads the legal speed limit is 50 $\mathrm{km} / \mathrm{h}$, the same value was used to categorize roads with different characteristics into higher or lower legal speed limits, which also points to the traffic conditions on individual roads.

The association test between pedestrian blackspots and the legal speed limit has determined that their association does exist $\left(\chi^{2}=12.175 / p=0.0005\right)$. The analysis of the contingencies table results (Table 7) and Figure 7 shows a higher probability of pedestrian 
Table 7 - Speed limit and pedestrian

blackspots - contingency table

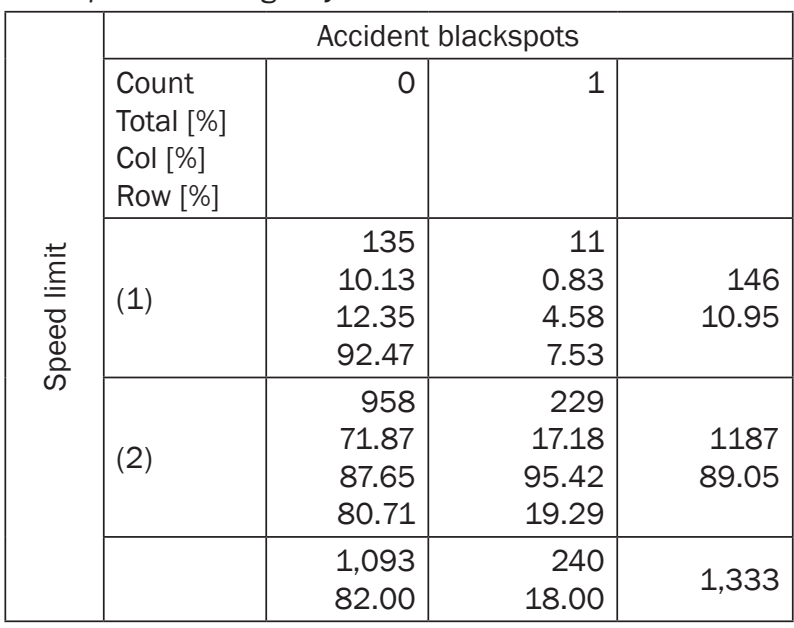

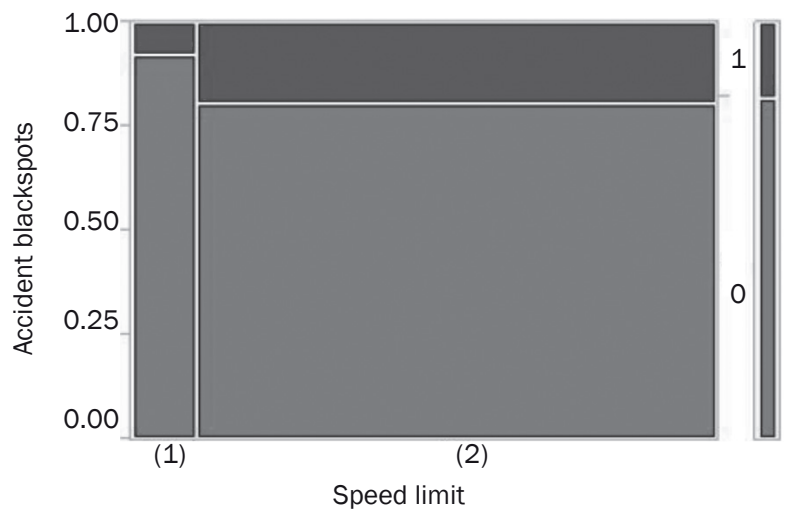

Figure 7 - Correlation of speed limit and pedestrian blackspots

blackspots on roads with a legal speed limit greater than $50 \mathrm{~km} / \mathrm{h}$. For the purposes of determining the association strength, a risk ratio of 2.934 was used, indicating that the probability for the emergence of pedestrian blackspots are almost three times higher on roads with legal speed limitations greater than 50 $\mathrm{km} / \mathrm{h}$ compared to others (confidence intervals are 1.561 and 5.515). On average, every $10^{\text {th }}$ traffic accident occurs $(10.95 \%)$ when the speed limit is under $50 \mathrm{~km} / \mathrm{h}$.

\section{Pedestrian volume}

For the purpose of determining the relationships between the pedestrian volume and the blackspots, based on the analysis of the road traffic network spatial database of the City of Zagreb, accidents were divided into two basic categories: road accidents with locations not representing the main pedestrian corridors (1), and accidents on roads representing the main pedestrian corridors (2) such as public transport corridors, associated facilities, areas around public, educational and health facilities as well as shopping centres. The intensity of traffic demand is based on the pedestrian corridors due to the lack of accurate data for each location. For the purpose of collecting data regarding pedestrian volumes, it would be necessary to carry out traffic counting at over 800 locations. The corridors are determined based on all available pedestrian traffic data, conducted targeted field surveys and counts for every blackspot identified by the research.

The association test between the emergence of pedestrian blackspots and the intensity of traffic demand determined that their association does exist $\left(\chi^{2}=244.163 / p=<0.0001\right)$. The analysis of the contingencies table results (Table 8 ) and Figure 8 shows a higher probability of pedestrian blackspots on roads that are being part of the pedestrian corridor. For the purpose of determining the association strength, a risk ratio of 19.438 was used, indicating that the probability for the emergence of pedestrian blackspots is 19 times higher on roads (locations) that are part of the pedestrian corridors (confidence intervals are 12.099 and 31.228 ). On average, every second traffic accident (46.14\%) occurs on pedestrian corridors. However, the share of traffic accidents on pedestrian corridors that occur at focal points represents $91.67 \%$ of the total number of traffic accidents occurring at focal points.

Table 8 - Pedestrian volume and pedestrian blackspots - contingency table

\begin{tabular}{|c|c|c|c|c|}
\hline \multirow{5}{*}{ 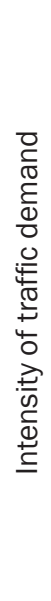 } & \multicolumn{4}{|c|}{ Accident blackspots } \\
\hline & $\begin{array}{l}\text { Count } \\
\text { Total [\%] } \\
\text { Col [\%] } \\
\text { Row [\%] }\end{array}$ & 0 & 1 & \\
\hline & (1) & $\begin{array}{r}698 \\
52.36 \\
63.86 \\
97.21\end{array}$ & $\begin{array}{r}20 \\
1.50 \\
8.33 \\
2.79\end{array}$ & $\begin{array}{r}718 \\
53.86\end{array}$ \\
\hline & $(2)$ & $\begin{array}{r}395 \\
29.63 \\
36.14 \\
64.23\end{array}$ & $\begin{array}{r}220 \\
16.50 \\
91.67 \\
35.77\end{array}$ & $\begin{array}{r}615 \\
46.14\end{array}$ \\
\hline & & $\begin{array}{l}1,093 \\
82.00\end{array}$ & $\begin{array}{r}240 \\
18.00\end{array}$ & 1,333 \\
\hline
\end{tabular}

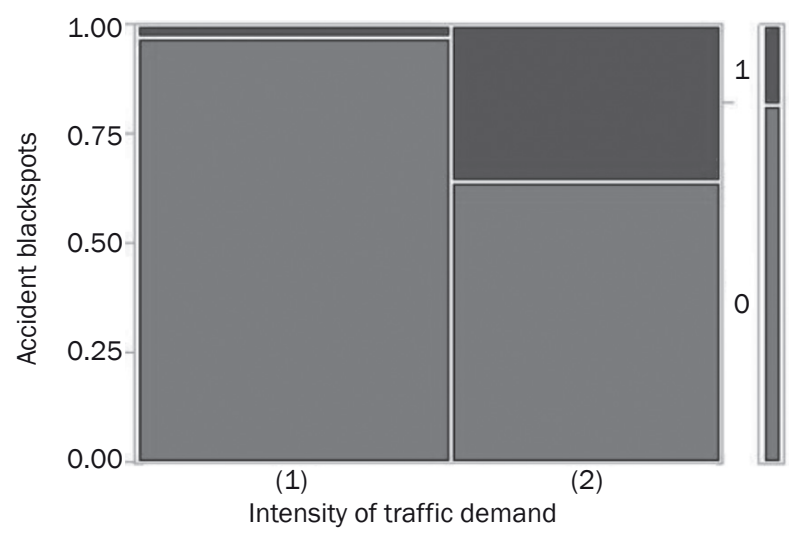

Figure 8 - Correlation between the intensity of traffic demand and pedestrian blackspots 


\section{Land use}

For the purpose of determining the relationships between the land use in zones where traffic accidents occur and the blackspots, based on the survey analysis regarding traffic accident and road traffic network spatial database of the city of Zagreb, traffic accidents were divided into three basic categories: residential and mixed use zones (1), public and business zones (2) and other zones (3) such as economic, sports and recreational zones and green zones. From the previously defined allocation of area land use, it is noticeable that most traffic accidents occur in residential and mixed-use zones as well as public and business zones.

The association test between the emergence of pedestrian blackspots and the land use has determined that their association does exist $\left(\chi^{2}=11.719\right.$ / $p=0.0029)$. The analysis of the contingencies table re-

Table 9 - Land use and pedestrian

blackspots - contingency table

\begin{tabular}{|c|c|c|c|c|}
\hline & & ccident & ppots & \\
\hline & $\begin{array}{l}\text { Count } \\
\text { Total [\%] } \\
\text { Col [\%] } \\
\text { Row [\%] }\end{array}$ & 0 & 1 & \\
\hline$\underset{N}{\mathscr{N}}$ & (1) & $\begin{array}{r}848 \\
63.62 \\
77.58 \\
83.46\end{array}$ & $\begin{array}{r}168 \\
12.60 \\
70.00 \\
16.54\end{array}$ & $\begin{array}{r}1016 \\
76.22\end{array}$ \\
\hline 侖 & (2) & $\begin{array}{r}150 \\
11.25 \\
13.72 \\
73.53\end{array}$ & $\begin{array}{r}54 \\
4.05 \\
22.50 \\
26.47\end{array}$ & $\begin{array}{r}204 \\
15.30\end{array}$ \\
\hline & (3) & $\begin{array}{r}95 \\
7.13 \\
8.69 \\
84.07\end{array}$ & $\begin{array}{r}18 \\
1.35 \\
7.50 \\
15.93\end{array}$ & $\begin{array}{r}113 \\
8.48\end{array}$ \\
\hline & & $\begin{array}{l}1,093 \\
82.00\end{array}$ & $\begin{array}{r}240 \\
18.00\end{array}$ & 1,333 \\
\hline
\end{tabular}

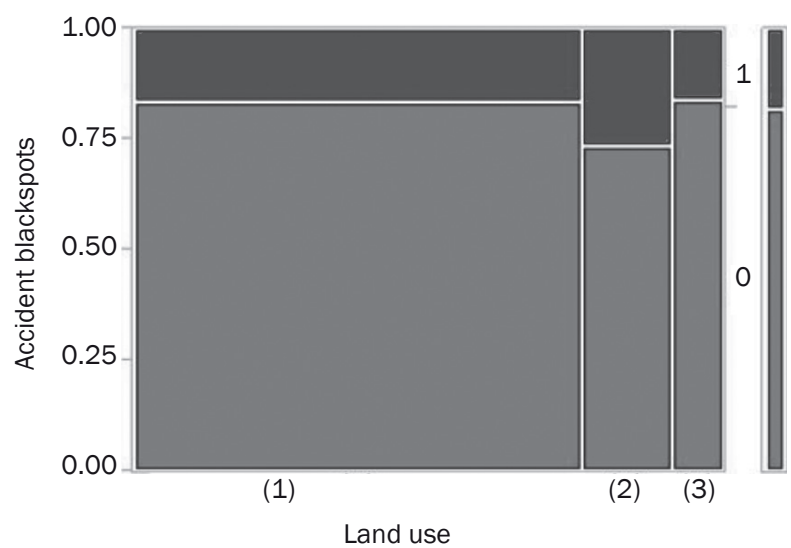

Figure 9 - Correlation of land use and pedestrian blackspots sults (Table 9) and Figure 9 show a higher probability of pedestrian blackspots in public and business zones, followed by residential and mixed use, while the lowest probability was noticed at other use zones. About $15.30 \%$ of traffic accidents occurred in public and business zones. The share of accidents in the mentioned zones that occurred at focal points represents $22.50 \%$ of the total number of traffic accidents at focal points.

\section{Period of the year}

Considering that traffic flows significantly oscillate during different periods of the year (e.g. tourist season), for the purpose of establishing relationships between the period of the year and the pedestrian blackspots, based on the survey data analysis, traffic accidents were divided into 12 categories according to the month in which they occurred. The classification of traffic accidents involving pedestrians into the beforementioned categories is based on the results of descriptive statistics which point to certain differences in the number of accidents depending on the weather conditions due to the period in a year. The association test between pedestrian blackspots and months in the year showed that an association does not exist $\left(\chi^{2}=8.394 / p=0.6776\right)$ and shown in Figure 10.

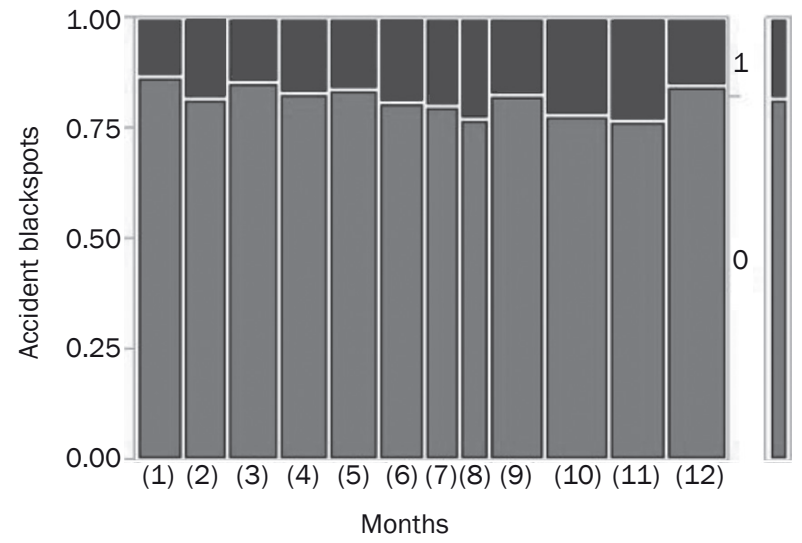

Figure 10 - Correlation between the period of the year and pedestrian blackspots

\section{Visibility conditions}

In order to determine the relationships between the visibility conditions and pedestrian blackspots, the accidents were divided into four categories depending on the visibility conditions: day (1), night (2), twilight (3) and sunset (4). The association test between the emergence of pedestrian blackspots and visibility conditions showed that an association does not exist $\left(\chi^{2}=11.719 / p=0.0029\right)$. The analysis of the contingencies table results (Table 10) and Figure 11 show a slight increase in the probability of pedestrian blackspots emerging during the night compared to the day. 
Table 10 - Visibility conditions and pedestrian blackspots - contingency table

\begin{tabular}{|c|c|c|c|c|}
\hline \multirow{7}{*}{ 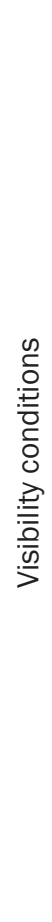 } & \multicolumn{4}{|c|}{ Accident blackspots } \\
\hline & $\begin{array}{l}\text { Count } \\
\text { Total [\%] } \\
\text { Col [\%] } \\
\text { Row [\%] }\end{array}$ & 0 & 1 & \\
\hline & (1) & $\begin{array}{r}772 \\
57.91 \\
70.63 \\
82.30\end{array}$ & $\begin{array}{r}166 \\
12.45 \\
69.17 \\
17.70\end{array}$ & $\begin{array}{r}938 \\
70.37\end{array}$ \\
\hline & $(2)$ & $\begin{array}{r}288 \\
21.61 \\
26.35 \\
80.90\end{array}$ & $\begin{array}{r}68 \\
5.10 \\
28.33 \\
19.10\end{array}$ & $\begin{array}{r}356 \\
26.71\end{array}$ \\
\hline & (3) & $\begin{array}{r}26 \\
1.95 \\
2.38 \\
81.25\end{array}$ & $\begin{array}{r}6 \\
0.45 \\
2.50 \\
18.75\end{array}$ & $\begin{array}{r}32 \\
2.40\end{array}$ \\
\hline & (4) & $\begin{array}{r}7 \\
0.53 \\
0.64 \\
100.00\end{array}$ & $\begin{array}{r}0 \\
0.00 \\
0.00 \\
0.00\end{array}$ & $\begin{array}{r}7 \\
0.53\end{array}$ \\
\hline & & $\begin{array}{l}1,093 \\
82.00\end{array}$ & $\begin{array}{r}240 \\
18.00\end{array}$ & 1,333 \\
\hline
\end{tabular}

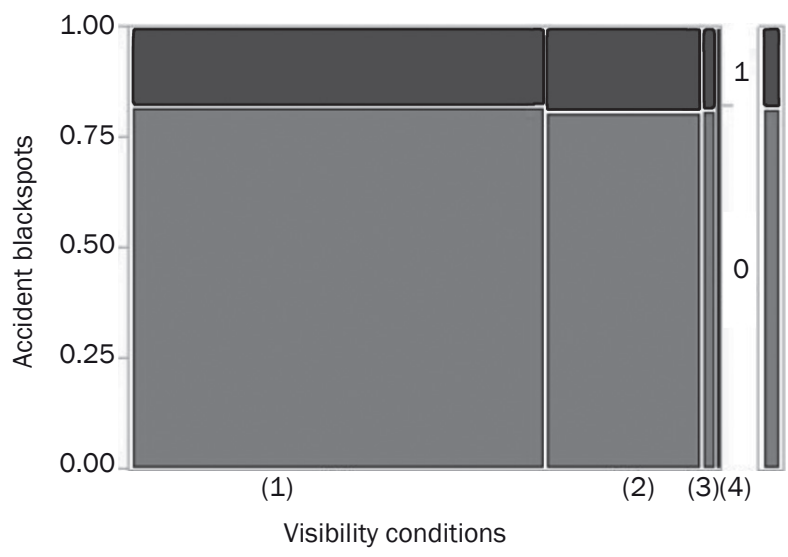

Figure 11 - Correlation of visibility conditions and pedestrian blackspots

\section{Atmospheric conditions}

To determine the relationships between atmospheric conditions and pedestrian blackspots, traffic accidents were divided into three categories, depending on the atmospheric conditions: clear (1), cloudy (2) and rain or other precipitation (3).

The association test between the emergence of pedestrian blackspots and atmospheric conditions showed that an association does not exist $\left(\chi^{2}=4.948 /\right.$ $p=0.0842)$. The analysis of the contingencies table results (Table 11) and Figure 12 showed a slightly higher proportion of traffic accidents occurring on blackspots during rainy conditions or involving other precipitation (23.35\%). The lowest number of traffic accidents occurred during the rainfall and other precipitation
(14.78\%), and the highest during clear weather conditions (51.99\%). However, the share of traffic accidents which occurred during rainfall and other precipitation at focal points represent $19.19 \%$ of the total number of traffic accidents occurring at focal points.

Table 11 - Atmospheric conditions and pedestrian blackspots - contingency table

\begin{tabular}{|c|c|c|c|c|}
\hline & & ccident & pots & \\
\hline & $\begin{array}{l}\text { Count } \\
\text { Total [\%] } \\
\text { Col [\%] } \\
\text { Row [\%] }\end{array}$ & 0 & 1 & \\
\hline 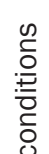 & (1) & $\begin{array}{r}579 \\
43.44 \\
52.97 \\
83.55\end{array}$ & $\begin{array}{r}114 \\
8.55 \\
47.50 \\
16.45\end{array}$ & $\begin{array}{r}693 \\
51.99\end{array}$ \\
\hline $\begin{array}{l}\frac{0}{0} \\
\frac{0}{0} \\
\frac{0}{0} \\
0 \\
\frac{0}{1}\end{array}$ & (2) & $\begin{array}{r}363 \\
27.23 \\
33.21 \\
81.94\end{array}$ & $\begin{array}{r}80 \\
6.00 \\
33.33 \\
18.06\end{array}$ & $\begin{array}{r}443 \\
33.23\end{array}$ \\
\hline & (3) & $\begin{array}{r}151 \\
11.33 \\
13.82 \\
76.65\end{array}$ & $\begin{array}{r}46 \\
3.45 \\
19.17 \\
23.35\end{array}$ & $\begin{array}{r}197 \\
14.78\end{array}$ \\
\hline & & $\begin{array}{l}1,093 \\
82.00\end{array}$ & $\begin{array}{r}240 \\
18.00\end{array}$ & 1,333 \\
\hline
\end{tabular}

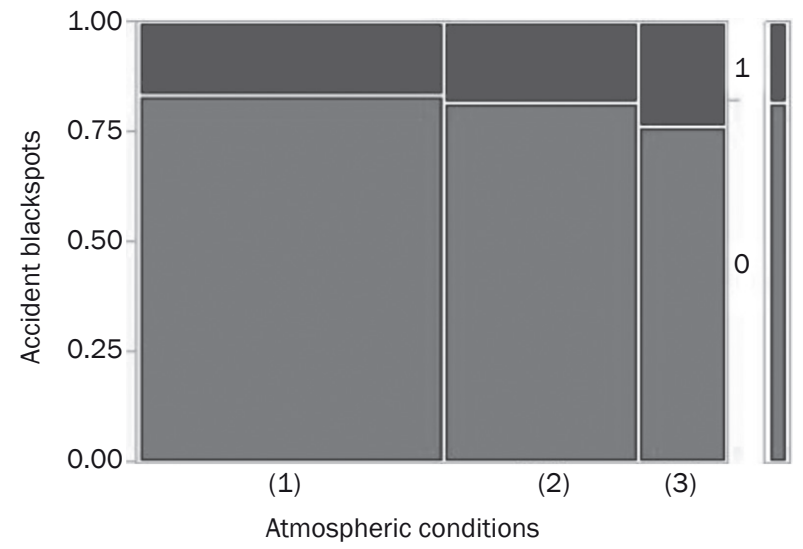

Figure 12 - Correlation of atmospheric conditions and pedestrian blackspots

\section{CONCLUSION}

Although the approach in researching traffic accidents has transformed from a traditional model into a systematic multidisciplinary approach, no scientifically based comprehensive model has been found to completely solve the problem of traffic accidents in urban areas yet. In the complex interaction between the main factors (man-vehicle-road) which lead to traffic accidents, the least explored area is the impact of the road infrastructure and its environment. This paper focuses on analysing pedestrian traffic accidents in the 
context of a complex urban environment. Numerous theoretical and field studies and statistical analyses were carried out in the paper, after which new findings indicating the influence of certain external factors on the occurrence of traffic accidents on the example of the City of Zagreb have been made.

The starting point, but also the prerequisite for this paper, was a sound database. It serves for a retrospective accident analysis and enables further research to be carried out. When collecting data, it is important that the data are: reliable (credible and certain), relevant (all essential traffic accident features are included) and equivalent (comparable with relevant databases).

For the purpose of the research, a statistical analysis was carried out in the SPSS program on a collection of traffic accident data representing pedestrian-vehicle accidents. Based on the initial descriptive analysis of traffic accidents that occurred in the City of Zagreb, it can be concluded that the percentage of pedestrian-vehicle accidents is increasing compared to the total number of traffic accidents and that pedestrians are the most vulnerable traffic participants.

Based on the local database and using the QGIS program, maps of traffic accidents that occurred in the City of Zagreb were visualized. Heat maps show locations with an increased density of accidents involving pedestrians, where different accident scenarios are visible.

Further analysis of influential factors tested the statistical determination in influence of certain factors on pedestrian accident blackspots. The association test between the blackspots and influential external factors determined that a statistical significance exists for these external factors: road category, road direction, number of traffic lanes, type of intersection, road characteristics, traffic regulations, speed limit, traffic volume and land use. There is no statistical significance for three external factors: the period in the year, visibility conditions and atmospheric conditions.

The results obtained give new insights and show that there is higher probability of traffic accidents occurring on primary roads in the cities. If these roads are one-way roads with two or more traffic lanes, and there are non-signalized pedestrian crossings and intersections in the area of public and business activities (generating significant pedestrian volume), then the odds for a traffic accident increase considerably.

It is important to note that there is a greater probability of a pedestrian blackspot forming on roundabouts than on three-legged and four-legged intersections. This points to the fact that roundabouts in urban areas with higher densities of pedestrian and motor traffic are dangerous from the standpoint of pedestrian traffic.
The results of the research will serve the project engineers and decision-makers to detect and inspect accident blackspots, with effectively eliminating the causes of traffic accidents on the existing infrastructure (a corrective action), avoiding mistakes in designing new roads (a preventive action), and provide information and warnings for pedestrians regarding the location of blackspots.

\section{Dr. sc. MARIO ĆOSIĆ ${ }^{1}$}

E-mail: mcosic@fpz.hr

Prof. dr. sc. LJUPKO ŠIMUNOVIĆ ${ }^{1}$

E-mail: ljsimunovic@fpz.hr

MARIJAN JAKOVLEVIĆ, doktorand ${ }^{1}$

${ }^{1}$ Sveučilište u Zagrebu, Fakultet prometnih znanosti

Vukelićeva 4, 10000 Zagreb, Hrvatska

\section{UTJECAJ VANJSKIH ČIMBENIKA NA NASTANAK OPASNIH MJESTA NA KOJIMA STRADAVAJU PJEŠACI - STUDIJA SLUČAJA GRAD ZAGREB}

\section{SAŽETAK}

Prometne su nesreće socijalni, javnozdravstveni i politički izazov svake države. U urbanim je sredinama karakteristično intenzivno prometno opterećenje cestovne mreže na kojoj se stalno izmjenjuju različiti prometni uvjeti koji dovode do međusobnih interakcija motoriziranoga i nemotoriziranoga prometa, što predstavlja potencijalnu opasnost za nastanak prometnih nesreća. lako su prometne nesreće s aspekta prostora i vremena slučajni događaji, detaljnom se analizom može uspostaviti korelacija između prometnih nesreća i vanjskih čimbenika (cestovna infrastruktura, prometni, vremenski uvjeti, namjena zemljišta). U radu je istražen utjecaj vanjskih čimbenika na nastanak žarišta prometnih nesreća pješaka u gradu Zagrebu. Kako bi utvrdili vanjske čimbenike koji dovode do stvaranja žarišta prometnih nesreća prvo su identificirana sama žarišta odnosno opasna mjesta, a potom se pristupilo analizi uzroka događanja prometnih nesreća. Provedenim istraživanjem su utvrđeni različiti stupnjevi utjecaja vanjskih čimbenika na nastanak opasnih mjesta.

\section{KLUUČNE RIJEČI}

prometna nesreća pješaka; opasno mjesto; vanjski čimbenik; test asocijacije; kontingencijska tablica;

\section{REFERENCES}

[1] Elvik R. A survey of operational definitions of hazardous road locations in some European countries. Accident Analysis \& Prevention. 2008;40(6): 1830-1835. Available from: doi:10.1016/j.aap.2008.08.001

[2] Sørensen M. Best Practice Guidelines on Black Spot Management and Safety Analysis of Road Networks. The Institute of Transport Economics-TOI; 2007. 66 p.

[3] Geurts K, Thomas I, Wets G. Understanding spatial concentrations of road accidents using frequent item sets. Accident Analysis \& Prevention. 2005;37(4): 787799. Available from: doi:10.1016/j.aap.2005.03.023

[4] Anderson TK. Kernel density estimation and K-means clustering to profile road accident hotspots. Accident 
Analysis \& Prevention. 2009;41(3): 359-364. Available from: doi: 10.1016/j.aap.2008.12.014

[5] Erdogan S, Yilmaz I, Baybura T, Gullu M. Geographical information systems aided traffic accident analysis system case study: city of Afyonkarahisar. Accident Analysis \& Prevention. 2008;40(1): 174-181. Available from: doi:10.1016/j.aap.2007.05.004

[6] Steenberghen T, Dufays T, Thomas I, Flahaut B. Intra-urban location and clustering of road accidents using GIS: a Belgian example. International Journal of Geographical Information Science. 2004;18(2): 169-181. Available from: doi:10.1080/1365881031 0001629619

[7] Noland RB, Quddus MA. A spatially disaggregate analysis of road casualties in England. Accident Analysis \& Prevention. 2004;36(6): 973-984. Available from: doi: 10.1016/j.aap.2003.11.001

[8] LaScala EA, Gerber D, Gruenewald PJ. Demographic and environmental correlates of pedestrian injury collisions: a spatial analysis. Accident Analysis \& Prevention. 2000;32(5): 651-658. Available from: doi:10.1016/S0001-4575(99)00100-1

[9] Blazquez CA, Celis MS. A spatial and temporal analysis of child pedestrian crashes in Santiago, Chile. Accident Analysis \& Prevention. 2013;50: 304-311.
Available from: doi:10.1016/j.aap.2012.05.001

[10] Priyantha Wedagama DM, Bird RN, Metcalfe AV. The influence of urban land-use on non-motorised transport casualties. Accident Analysis \& Prevention. 2006;38(6): 1049-1457. Available from: doi:10.1016/j.aap.2006.01.006

[11] Šimunović L, Novačko L, Ćosić M. Road Network Safety Management in the Republic of Croatia. Modern Traffic. 2014. p. 240-244.

[12] Hrvatske ceste d.o.o. Metodologija pristupa sigurnosti prometa. Zagreb; 2004. Croatian

[13] Plug C, Xia J, Caulfield C. Spatial and temporal visualisation techniques for crash analysis. Accident Analysis \& Prevention. 2011;43(6): 1937-1946. Available from: doi:10.1016/j.aap.2011.05.007

[14] Levine N. Part IV: Spatial Modeling I Chaper 10: Kernel Density Interpolation. Washington DC; 2014.

[15] Siddiqui C, Abdel-Aty M, Choi K. Macroscopic spatial analysis of pedestrian and bicycle crashes. Accident Analysis \& Prevention. 2012;45: 382-391. Available from: doi:10.1016/j.aap.2011.08.003

[16] Gradski ured za strategijsko planiranje i razvoj grada Odjel za statistiku. Statistički ljetopis Grada Zagreba. Zagreb; 2015. Croatian 